\title{
Prevalence of Retromolar Foramen in Dry Human Mandibles: A Cross-sectional Study
}

\section{ABSTRACT}

Introduction: Retromolar foramen present in the retromolar area is related with neurovascular contents, which can be manipulated in surgical procedures. So the knowledge of the presence of foramen is important. In this study, presence of retromolar foramen is identified on dry mandibles.

Aim: The aim of the study is to determine the prevalence of the retromolar foramen, its size and shape and the distance of the retromolar foramen from the last socket and the anterior border of mandible and its clinical implications.

Materials and Methods: This was a cross-sectional study conducted for a period of three months from September 2019 to November 2019. Forty mandibles were observed on both sides for the presence of the retromolar foramen and its size was measured with a divider and ruler to the nearest millimeters and its shape was observed. The distances of the foramen from last molar socket and also from the anterior border of the mandible were measured with a divider and ruler to the nearest millimeters.

Results: Among the 80 sides, on 9 sides (11.25\%) retromolar foramen was found: $5(6.25 \%)$ on right side, $2(2.5 \%)$ on left side and 1 (1.25\%) bilaterally.

Conclusion: According to the present study retromolar foramen can be sometimes observed in mandibles. For surgical and anaesthetical procedures in the retromolar area, retromolar foramen is considered as the neurovascular bundle passing through it.

\section{INTRODUCTION}

Retromolar foramen in mandible, when present is situated in the triangular area behind the lower last molar tooth, boundaries of retromolar fossa are anterior to the base of third molar tooth, medially temporal crest and laterally anterior border of ramus [1-4]. Neurovascular bundle passes through it, which includes branches of inferior alveolar nerve and artery [5]. The mandibular third molar and associated tissues may be innervated by this bundle. These structures may be the reason for local anaesthetic failure and local haemorrhage during surgery [6]. It is mentioned in the literature but ignored by the surgeons and conventional panoramic radiographs are also not capable of showing these foramina satisfactorily $[1,7-10]$. In the present study, presence of retromolar foramen in dry human mandibles of age 40 to 60 years was identified. Its size, shape, distance of the retromolar foramen from the last socket and the anterior border of mandible were studied.

\section{MATERIALS AND METHODS}

After ethical permission, cross-sectional study was conducted in the Department of Anatomy, Government Medical College, Mahabubnagar, Telangana, India for three months from September 2019 to November 2019.

Inclusion and Exclusion criteria: All the mandibles available in museum were included; bones with deformities and fracture were excluded.

Forty dry human mandibles of age 40 to 60 years were examined both sides for the presence of retromolar was noticed. Presence of retromolar foramen is noted behind the last molar tooth in each mandible [Table/Fig-1]. Size and shape and the distance of the retromolar foramen from the last socket and anterior border of mandible were measured with a divider [Table/Fig-2] and ruler to the nearest millimeters.
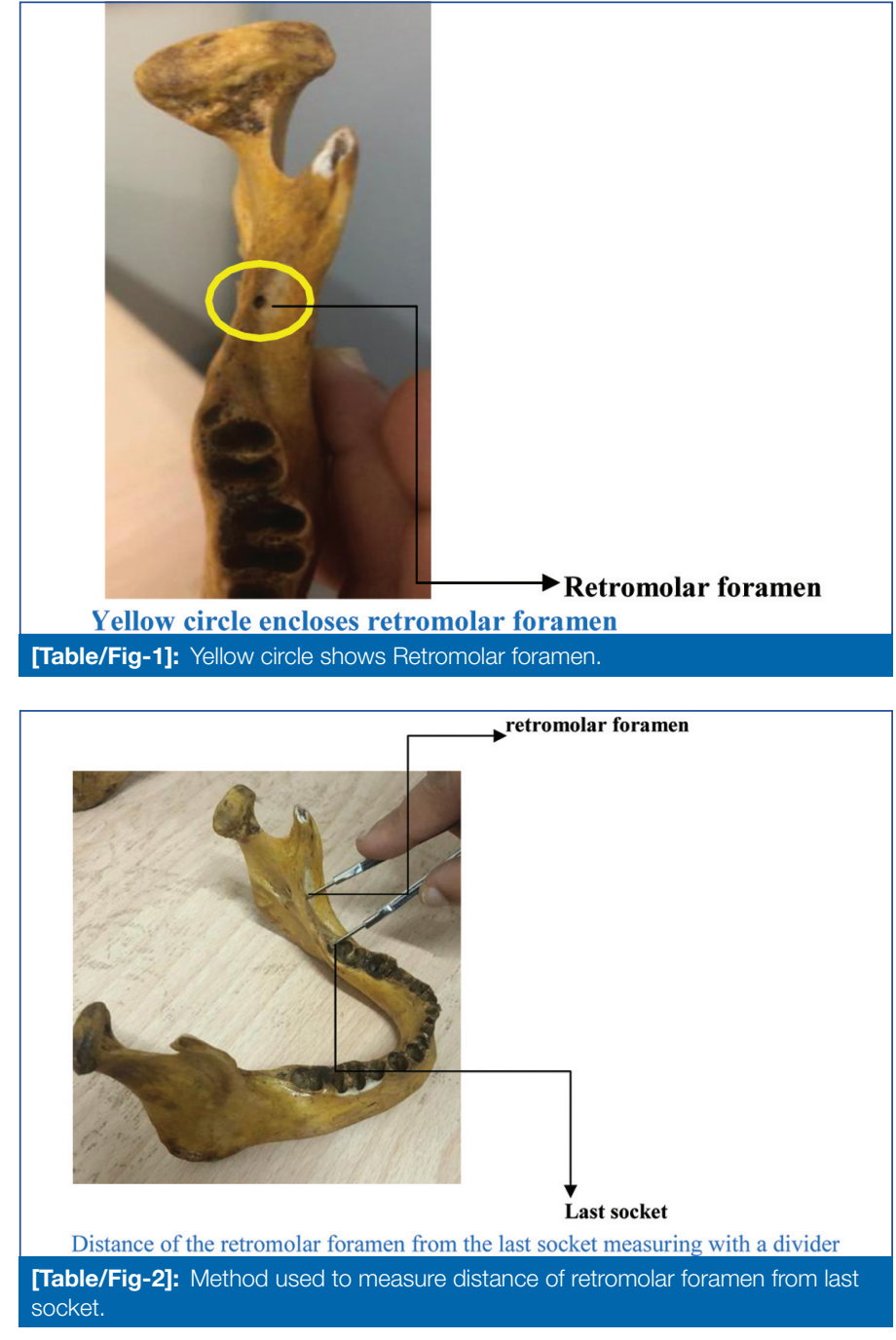


\begin{tabular}{|c|c|c|c|c|c|c|c|c|c|c|}
\hline \multirow{2}{*}{$\begin{array}{l}\text { No. of the } \\
\text { specimen } \mathrm{N}\end{array}$} & \multicolumn{2}{|c|}{ Position } & \multicolumn{2}{|c|}{ Shape } & \multicolumn{2}{|c|}{ Diameter in $\mathrm{mm}$} & \multicolumn{2}{|c|}{$\begin{array}{l}\text { Distance from last } \\
\text { socket in } \mathrm{mm}\end{array}$} & \multicolumn{2}{|c|}{$\begin{array}{l}\text { Distance from anterior } \\
\text { border of ramus of } \\
\text { mandible in mm }\end{array}$} \\
\hline & Right & Left & Right & Left & Right & Left & Right & Left & Right & Left \\
\hline N8 & Present & Absent & Small round & - & $\begin{array}{l}\text { Can't be } \\
\text { measured as it is } \\
\text { too small }\end{array}$ & - & 5 & - & 10 & - \\
\hline N16 & Present & Absent & Round & - & 1 & - & 8 & - & 10 & - \\
\hline N19 & Absent & Present & - & Round & - & 2 & - & 7 & - & 12 \\
\hline N22 & Present & Present & Round & Small round & 5 & $\begin{array}{l}\text { Can't be } \\
\text { measured as it is } \\
\text { too small }\end{array}$ & 5 & 5 & 5 & 6 \\
\hline N24 & Absent & Present & - & Round & - & 3 & - & 8 & - & 7 \\
\hline N27 & Present & Absent & Oval & - & 4 & - & 5 & - & 8 & - \\
\hline N33 & Present & Absent & Slit like & - & 2 & - & 3 & - & 5 & - \\
\hline N36 & Present & Absent & Small & - & $\begin{array}{l}\text { Can't be } \\
\text { measured as it is } \\
\text { too small }\end{array}$ & - & 7 & - & 10 & - \\
\hline
\end{tabular}

\section{RESULTS}

Retromolar foramen was found in 8 of 40 mandibles (20\%) of which 5 on the right side (12.5\%) and 2 on left side (5\%) and 1 bilaterally (2.5\%), The longest distance between last socket to the retromolar foramen was found to be $8 \mathrm{~mm}$ on the both the sides. Longest distance between anterior border of ramus to retromolar foramen was found to be $10 \mathrm{~mm}$ on the right side and $12 \mathrm{~mm}$ on the left side [Table/Fig-3].

\section{DISCUSSION}

Accessory branches of the inferior alveolar neurovascular bundles pass through retromolar foramen to supply tissues at the retromolar trigone. As retromloar foramen is located in the posterior part of the mandible surgery in this area should be cautiously done [11]. Retromolar trigone is the area most of the time involved during surgeries related with third molar tooth, fractures of mandible in that region, for bone grafting in the same individual and also repairing of the mandible. There are few available technologies to detect retromolar foramen such as computed tomography, cone beam computed tomography and panoramic radiography with cone beam computed tomography being the most sensitive technique [3]. According to Potu BK et al., in 11 out of 94 mandibles retromolar foramen were found $(11.7 \%)$ in three mandibles, the foramen was present bilaterally (3.2\%), in three it was on the left side (3.2\%) and in five it was on the right side (5.3\%) [1]. According to Ossenberg NS incidence of retromolar foramen was more common in native populations of North America than in other populations like Africa, Europe, India and northeast Asia [12]. Sawyer DR and Kiely ML concluded retromolar foramen was found to occur in 18 of 234 adult human mandibles studied (7.7\%) and no statistically significant difference was found between left and right sides or between sexes [13]. Bilecenoglu B et al., found retromolar foramen 10 (25\%) out of 40 mandibles they studied [7]. In the present study, incidence of retromolar foramen is $20 \%$. Results of present study were coinciding with Kondera $\mathrm{H}$ and Hashimoto I [5]. According to Truong MK et al., frequency of retromolar foramen reported by human dry mandible studies ranges from $3.2 \%$ to $72 \%$, by the cone beam computed tomography studies ranges from $5.4 \%$ and $75.4 \%$ and by the Panoramic Radiography studies ranges from $3.06 \%$ to $8.8 \%$ [3]. This large range can be attributed to different factors which include genetic, environmental, ethnicity and sample size variations in different studies. Studies have suggested the retromolar foramen is normal anatomical variation of mandible and will be useful for further studies, if it is considered along with other variations of skull [14].

\section{Limitation(s)}

In the present study the sample size was small, study was done on dry human mandibles and sex differentiation was not done.

\section{CONCLUSION(S)}

The results of this study suggest that retromolar foramen variations are common and different among individuals. It is important to locate anatomic variants of retromolar foramen before performing the surgical procedures in the retromolar area and to achieve full anaesthesia. As variations in retromolar foramen are common, it is important for the dental practitioner to be aware of these variations and also of possible complications which may occur during the administration of anaesthesia and surgical procedures in retromolar area and mandible. Retromolar foramen may interfere in the placement of dental implants and fabrication of dental prostheses. In future, studies can be undertaken to check the prevalence of retromolar foramen and the canal with the help of radiological interventions in live subjects for better understanding of clinical aspects related with it.

\section{REFERENCES}

[1] Potu BK, Kumar V, Salem AH, Abu-Hijleh M. Occurrence of the retromolar foramen in dry mandibles of south-eastern part of India: A morphological study with review of the literature. Anatomy Research International. 2014:296717. 5 pages. doi.org/10.1155/2014/296717.

[2] Park MK, Jung W, Bae JH, Kwak HH. Anatomical and radiographic study of the mandibular retromolar canal. J Dent Sci. 2016;11:370-76.

[3] Truong MK, He P, Adeeb N, Oskouian RJ, Tubbs RS, Iwanaga J. Clinical anatomy and significance of the retromolar foramina and their canals: A literature review. Cureus. 2017;9:e1781.

[4] Freitas GB de, Freitas E Silva A de, Manhães Júnior LRC. The prevalence of mandibular retromolar canals on cone beam computed tomography and its clinical reperecussions. Rev Odontol. 2017;46:158-63.

[5] Kondera $\mathrm{H}$, Hashimoto I. A case of mandibular retromolar canal; elements of nerve and arteries in this canal. Kaibogaku-Zasshi. 1995;70:23-30.

[6] Gamieldien MY, Van Schoor A. Retromolar foramen: An anatomical study with clinical considerations. Br J Oral Maxillofac Surg. 2016;54(7):784-87.

[7] Bilecenoglu B, Tuncer N. Clinical and anatomical study of retromolar foramen and canal. J Oral Maxillofac Surg.2006:64(10):1493-97.

[8] von Arx T, Hänni A, Sendi P, Buser D, Bornstein MM. Radiographic study of the mandibular retromolar canal: An anatomic structure with clinical importance. J Endod. 2011;37(12):1630-35.

[9] Lizio G, Pelliccioni GA, Ghigi G, Fanelli A, Marchetti C. Radiographic assessment of the mandibular retromolar canal using cone-beam computed tomography. Acta Odontol Scand. 2013;71(3-4):650-55.

[10] Han SS, Hwang YS. Cone beam CT findings of retromolar canals in a Korean population. Surg Radiol Anat. 2014;36(9):871-76.

[11] Ngeow WC, Chai WL. The clinical significance of the retromolar canal and foramen in dentistry. Clinical Anatomy. 2020. doi.org/10.1002/ca.23577. 
[12] Ossenberg NS. Retromolar foramen of the human mandible. Am J Phys Anthropol. 1987;73(1):119-28.

[13] Sawyer DR, Kiely ML. Retromolar foramen: A mandibular variant important to dentistry. Ann Dent. 1991;50(1):16-18.
[14] Jacob M, Avadhani R, Bindhu S, Nallathamby R, Soman MA. Prevalence of retromolar foramen in human mandibles and its clinical significance. Int $\mathrm{J}$ Anat Res. 2014;2(3):553-56.

\section{PARTICULARS OF CONTRIBUTORS:}

1. Professor, Department of Anatomy, Osmania Medical College, Koti, Hyderabad, Telangana, India.

2. Associate Professor, Department of Anatomy, Malla Reddy Medical College for Women, Suraram, Telangana, India.

3. Assistant Professor, Department of Anatomy, Gandhi Medical College, Secunderabad, Hyderabad, Telangana, India.

\section{NAME, ADDRESS, E-MAIL ID OF THE CORRESPONDING AUTHOR:}

Manasa Bethi,

H. No. 11-10-116/5, Plot No. 3, Road No. 1, Vijayapuri Colony, Kothapet,

E-mail: manasabethi6@gmail.com
Hyderabad, Telangana-500035, India.

\section{PLAGIARISM CHECKING METHODS: [Jain Het al.]}

- Plagiarism X-checker: Sep 22, 2020

- Manual Googling: Jan 25, 2021

- iThenticate Software: Jan 04, 2021 (24\%)
ETYMOLOGY: Author Origin

\section{AUTHOR DECLARATION:}

- Financial or Other Competing Interests: None

- Was Ethics Committee Approval obtained for this study? Yes

- Was informed consent obtained from the subjects involved in the study? NA

- For any images presented appropriate consent has been obtained from the subjects.
Date of Submission: Sep 20, 2020 Date of Peer Review: Dec 11, 2020 Date of Acceptance: Jan 27, 2021 Date of Publishing: Jul 01, 2021 